\title{
Educating the Muslims of America
}

Yvonne Y. Haddad, Farid Senzai, and Jane I. Smith, eds. New York: Oxford University Press, 2009. 277 pages.

This pioneering volume brings together many different voices in an attempt to tackle various aspects of this topic. The introduction, written by Yvonne Y. Haddad and Jane I. Smith, contextualizes the volume's importance within some of the growing hostility voiced in the American media as regards to the supposed association of Muslim madrasas and "home-grown terrorism." They highlight the magnified threefold importance of Muslim education in America as serving to improve Islamic education, dispel myths, and educate the American public. They also give a brief history of Muslim education here and trace the growth of full- and part-time Muslim schools.

Chapter 1, "Islamic Schools of America: Data-Based Profiles" by Karen Keyworth, presents statistics on the numbers of full-time Muslim schools; however, there is not much interpretation. The conclusion vaguely points to how to use the "facts" given for the potential development of schools. The second chapter, Jasmine Zine's "Safe Havens or Religious 'Ghettos'? Narratives of Islamic Schooling in Canada," is the only chapter on non-American schools, making for the weak generalization that this volume is about North America. Zine, who selected two schools in Greater Toronto, emphasizes the anecdotal to paint a vivid portrait of the pros and cons of private Islamic education in the western context in the words of the users.

Chapter 3, "The Case for the Muslim School as a Civil Society Actor" by Louis Cristillo, approaches private Islamic schools from the vantage point of community involvement. This approach nicely counterbalances the previous two chapters' focus on the quality of education. Cristillo empha- 
sizes the important role these schools have vis-à-vis participating in the larger secular society. Using examples from New York City, as well as statistics, interviews, and anecdotal descriptions, he draws a clear, positive, and proactive picture of the important potential of this aspect of Islamic schooling in the United States.

Deepening the discussion of an Islamic school's purpose and creation, chapter 4 consists of Susan L. Douglass' "Teaching about Religion, Islam, and the World in Public and Private School Curricula." Countering the argument that many American Islamic private schools fall into the "double curriculum" syndrome by adopting (free) state textbooks and adding "Islamic" subjects, she shows how Catholic school curriculum development takes advantage of small class sizes and a shared vision by infusing and integrating subjects in a manner that is refreshing for students, hands-on, and encourages further exploration.

The fifth chapter, "Muslim Home Schooling" by Pricilla Martinez, delves into home schooling using both anecdotal and academic evidence. Using her personal experience, she makes the case for its benefits: in-depth study, higher academic achievement, customized learning, freedom of lifestyle, and "keeping safe" from negative peer pressure. She argues that the qualities inherent in home schooling in general suit the idea of Muslim education in particular.

Chapter 6 looks at some fledgling college-level programs. Nadia Inji Khan's “"Guide Us to the Straight Way': A Look at the Makers of the 'Religiously Literate' Young Muslim Americans” looks at how some American Muslim college-aged students further their knowledge of Islam. The chapter discuss the motives and proceeds in anecdotal form to describe the author's first-hand experiences. In general, she states that all programs need to separate culture from practice.

Chapter 7, Yasmin Moll's "Screening Faith, Making Muslims: Islamic Media for Muslim American Children and the Politics of Identity Construction," tackles the growing production of American-made Muslim media that targets children with a hybrid background. After analyzing four video programs to find recurring themes, she concludes that three of them are isolationist in approach. Like many other aspects of Muslim education in America, these are still pioneering efforts. Moll clearly describes the issues and provides a balanced analysis of prominent examples.

Chapter 8, "The Search for Justice: Islamic Pedagogy and Inmate Rehabilitation" by Anna Bowers, focuses on the growing conversion and practice of Islam in American prisons, the role of prison imams, and the shortage of institutional support. Beginning with clear statistics of the number of inmates 
in general and of Muslims inmates in particular, Bowers states that the percentages of rehabilitated Muslims are far lower than others in terms of recidivism. The chapter concludes with six pro-active recommendations to improve Islamic education in prison.

The ninth chapter, Shabana Mir's “"I Didn't Want to Have That Outcast Belief about Alcohol': Muslim Women Encounter Drinking Cultures on Campus," has a rather weak premise: Muslim women's identity in college partially - or largely - revolves around the consumption (or abstention) of alcohol. This stretches the importance of this issue. Other clearly visible issues such as dress and general behavior are skirted in favor of this purely anecdotal and partial description. It is a pity she did not engage deeply with the issues of college education of Muslims in America and the resulting avenues of identity created.

Chapter 10, "Authentic Interactions Eliminating the Anonymity of Otherness" by Barbara Sahili, Christina Safiya Tobias-Nahi, and Mona AboZena, vividly portrays the opportunities of primary Muslim schools that regularly engage and invite groups from local public schools. The chapter focuses on the mutual benefits of Muslim students (at a Muslim school) presenting Islam to non-Muslim student groups. The chapter's optimistic tone, along with the substantiated research and description, highlight some of the great potentials that Muslim schools have in America. The final chapter, Farid Senzai's "The Outlook for Islamic Education in America," begins with a summary paragraph reviewing some of the ideas covered in the volume but goes on to emphasize the problems and needs projected for developing the primary education of Muslims.

All contributions highlight the many issues related to the topic as well as the need for continued research. Given that seven of the eleven chapters revolved around the relation of primary/secondary schools to Islam, the other aspects of Islam and education in America are not fully presented. The emphasis on primary education detracts from the larger picture of education and Islam that is initially projected.

Despite some of the shortcomings mentioned, however, this volume is a laudable effort to bring to the forefront the intrinsically important and relevant impact of Islamic education in America and is a must-read for academics and Muslim students and parents living in the diaspora.

Tammy Gaber (gaber@bue.edu.eg) Assistant Professor of Architecture, Department of Architecture Faculty of Engineering, British University in Egypt Adjunct Professor, Department of Performing Visual Arts 